\title{
WORKSHOP PENYUSUNAN RENCANA PENGEMBANGAN KOMUNITAS BELAJAR PROFESIONAL GURU DI SDN 10 MATARAM DAN SDN 30 MATARAM
}

\author{
Lalu Hamdian Affandi ${ }^{1 *}$, Heri Hadi Saputra ${ }^{1}$, Husniati ${ }^{1}$, Ida Ermiana ${ }^{1}$ \\ 1Program Studi PGSD, FKIP, Universitas Mataram \\ *Co-Author : hamdian.fkip@unram.ac.id
}

\begin{abstract}
ABSTRAK. Kegiatan pengabdian kepada masyarakat ini bertujuan memfasilitasi guru mengidentifikasi tantangan dan rencana pengembangan komunitas belajar professional di sekolah. Kegiatan ini dilaksanakan dengan metode ceramah, tanya jawab, dan diskusi kelompok. Kegiatan pengabdian ini telah dilaksanakan pada tanggal 8 Agustus 2019 di SDN 30 Mataram dengan dihadiri oleh guru dari SDN 30 Mataram dan SDN 10 Mataram yang berjumlah 27 orang. Melalui sesi diskusi dan Tanya jawab, tim pelaksana membangun kesepahaman dengan guru tentang pentingnya komunitas belajar professional sebagai alternative untuk mengembangkan profesionalisme guru dan perbaikan kualitas pembelajaran bagi siswa. Melalui sesi diskusi kelompok, guru secara bersama-sama dengan didampingi tim pelaksana pengabdian mengidentifikasi tantangan untuk selanjutnya menyusun rencana pengembangan komunitas belajar professional di sekolah. Beberapa tantangan yang dihadapi guru adalah budaya sekolah yang tidak sesuai dengan prinsip-prinsip komunitas belajar professional, kurangnya dukungan dari tenaga ahli dan kepala sekolah, serta manajemen sekolah yang tidak akomodatif terhadap pengembangan komunitas belajar professional. Sedangkan rencana pengembangan komunitas belajar professional yang disepakati guru melalui kegiatan diskusi kelompok adalah menyiapkan sarana pendukung komunitas belajar professional, mengembangkan budaya sekolah yang lebih suportif terhadap eksistensi komunitas belajar professional, serta menjadikan pengembangan komunitas belajar professional sebagai bagian dari program kerja kepala sekolah. Kegiatan pengabdian kepada masyarakat ini merekomendasikan agar sekolah membangun kolaborasi dengan kalangan perguruan tinggi sehingga mereka mendapatkan pendampingan yang lebih terorganisir dalam mengembangkan komunitas belajar professional.
\end{abstract}

Kata Kunci: komunitas belajar professional, pengembangan profesionalisme guru SD

\begin{abstract}
This community service activity aims to facilitate teachers in identifying challenges and plans for developing professional learning communities in schools. This activity was carried out using lecture, question and answer, and group discussion methods. This dedication activity was carried out on August 8, 2019 at SDN 30 Mataram and was attended by 27 teachers from SDN Mataram and SDN 10 Mataram. Through discussion and question and answer sessions, the implementation team built an understanding with the teacher about the importance of the professional learning community as an alternative to developing teacher professionalism and improving the quality of learning for students. Through group discussion sessions, the teacher together accompanied by a service implementation team identifies the challenges to further develop a plan for developing a professional learning community at school. Some of the challenges faced by teachers are school culture that is not in accordance with the principles of the professional learning community, lack of support from experts and principals, and school management that is not accommodating to the development of professional learning communities. While the professional learning community development plan agreed upon by the teacher through
\end{abstract}


group discussion activities is to prepare a means of supporting the professional learning community, develop a school culture that is more supportive of the existence of a professional learning community, and make the development of a professional learning community as part of the principal's work program. This community service activity recommends that schools build collaboration with tertiary institutions so that they get more organized assistance in developing professional learning communities.

Keywords: professional learning community, elementary teacher professional development

\section{PENDAHULUAN}

Pembelajaran yang efektif membutuhkan kehadiran sosok guru yang kompeten, yaitu guru yang memiliki kapabilitas untuk merancang, melaksanakan, dan mengevaluasi pembelajaran dengan baik. Pembelajaran yang efektif adalah pembelajaran yang dilaksanakan dengan strategi yang efektif, pengelolaan kelas yang efektif, serta desain kurikulum yang efektif pula (Marzano, 2007; 5). Pembelajaran yang efektif terwujud melalui perilaku guru yang meliputi kejelasan penjelasan guru, variasi cara mengajar, orientasi tugas, dan optimalisasi keterlibatan belajar siswa (Borich, 1996; 11). Artinya, pembelajaran yang efektif hanya bisa dilakukan oleh guru yang memiliki kompetensi yang sesuai dengan persyaratan perundang-undangan.

Kompetensi seorang guru dapat dilihat dari kinerjanya dalam menyelenggarakan pembelajaran. Berdasarkan penelitian yang pernah dilakukan melaporkan bahwa $36 \%$ lebih guru menunjukkan kinerja sedang atau buruk aspek perencanaan dan $17 \%$ lebih guru berkinerja sedang dan buruk pada aspek pelaksanaan pembelajaran. Kinerja guru dalam pelaksanaan pembelajaran dilihat berdasarkan variasi metode dan media yang digunakannya dalam pembelajarannya (Husniati, Affandi, Saputra, Makki, 2016). Dalam implementasi kurikulum 2013, guru dituntut lebih kreatif dalam menyelenggarakan pembelajaran. Karakteristik K13 dengan pendekatan saintifik dalam bentuk tema-tema tertentu, menjadi tantangan tersendiri bagi guru.

Pada aspek pelaksanaan pembelajaran, observasi yang dilakukan dalam penelitian sebelumnya menunjukkan bahwa keterampilan mengajar guru relative masih rendah. Keterampilan mengajar seperti membuka pelajaran, mengajukan pertanyaan, mengadakan variasi, serta mengelola kelas adalah keterampilan mengajar yang seringkali tidak terobservasi (Ermiana, Affandi, Saputra, dan Witono, 2018). Pada kesempatan lain beberapa guru mengeluhkan susahnya mengontrol perilaku siswa yang seringkali menjadi gangguan terhadap kelancaran pembelajaran. Akibat sulitnya mengontrol perilaku siswa banyak guru mengaku tertekan dan tidak bahagia dengan profesinya sebagai guru.

Para guru bukannya tidak pernah berusaha untuk memecahkan masalah yang mereka hadapi. Salah satu upaya mereka memecahkan masalah tersebut adalah dengan mendiskusikannya dengan sejawatnya. Namun biasanya hasil diskusi sejawat secara informal tersebut tanpa solusi. Walhasil, permasalahan yang dihadapi guru terus berulang tanpa solusi yang memadai.

Jika dijabarkan lebih detil, persoalan kinerja guru dalam perencanaan pembelajaran memiliki akar pada tidak adanya mekanisme yang bisa menjamin guru yang menghadapi masalah dalam pembelajaran untuk mendapatkan asupan solusi yang sesuai. Dalam kaitan dengan perencanaan pembelajaran, guru seringkali hanya menyalin kegiatan yang tercantum di dalam buku guru dan buku siswa ke dalam rencana pembelajaran yang akan dilaksanakannya. Begitu pun halnya dengan 
materi ajar yang hendak disampaikan. Pada aspek perencanaan evaluasi, guru seringkali hanya menyandarkan diri pada soal yang terdapat di LKS yang diperdagangkan dengan bebas. Beberapa guru mengaku mereka melakukan itu karena tidak memiliki cukup kemampuan untuk menyusun perencanaan pembelajaran yang sesuai dengan tujuan, karakteristik siswa, serta kondisi sekolah.

Namun demikian, kenyataan yang penulis temui dalam serangkaian observasi dan wawancara di sekolah dasar di kota mataram menunjukkan bahwa banyak guru memiliki tingkat kesiapan yang rendah dalam menerapkan $\mathrm{K} 13$. Hal ini terlihat dari kecenderungan guru untuk menulis ulang aktifitas yang terdapat di dalam buku guru dan buku siswa ke dalam rencana pembelajaran yang hendak diterapkannya. Dalam praktiknya, RPP yang telah disusun berdasarkan buku guru dan buku siswa tersebut seringkali kehilangan muatan saintifiknya karena guru tidak memiliki pemahaman yang memadai. Dalam kesempatan wawancara yang lain, banyak guru mengakui minimnya pengetahuan mereka tentang model-model pembelajaran inovatif yang dapat digunakan sebagai alternatif penerapan pendekatan saintifik. Mereka memang banyak mendapatkan pengetahuan dari pelatihan yang telah mereka ikuti. Namun pada tataran implementasi hasil pelatihan, mereka seringkali kehilangan arah sehingga kembali kepada kebiasaan awal seperti sebelum mendapatkan pelatihan.

Dalam situasi seperti di atas, para guru biasanya menunggu datangnya kesempatan lain untuk mengikuti pelatihan. Karena pelatihan seringkali tidak bisa mengakomodir semua guru untuk berpartisipasi, maka permasalahan yang dihadapi guru kembali terpendam tanpa solusi yang jelas. Jika pun para guru yang menghadapi masalah tersebut mencari solusi dari teman sejawat, biasanya solusi tersebut hanya berlalu seiring obrolan ringan tanpa tindak lanjut.

Persoalan lemahnya pola kolaburasi antarguru dalam menyelesaikan masalah pembelajaran tentunya perlu mendapatkan perhatian serius. Kebijakan pemerintah membentuk Kelompok Kerja Guru (KKG) sejatinya bertujuan memfasilitasi guru untuk memecahkan masalah pembelajaran yang mereka hadapi. Dalam KKG yang terkelola dengan baik, guru dapat dengan mudah mendiskusikan masalah pembelajarannya dan mendapatkan respon yang antusias dari sejawat, bahkan kepala sekolah dan pengawas sekolah. Sebaliknya, dalam KKG yang tidak terkelola dengan baik guru seringkali melupakan persoalan nyata yang mereka hadapi. Dan KKG pun berubah menjadi ajang diskusi masalah lain yang tidak terkait dengan persoalan pembelajaran.

Persoalan rendahnya kinerja guru yang berkelindan dengan ketiadaan mekanisme pemecahan masalah yang berbasis inisiatif dan kreatifitas guru bisa diatasi dengan berbagai alternatif. Salah satu alternatif yang terbukti secara ilmiah dapat menjadi solusi yang layak ditawarkan adalah membangun kolaburasi antarguru dalam bentuk komunitas belajar professional. Komunitas belajar professional dalam bentuk lesson study berhasil merubah kultur pembelajaran guru dan pada gilirannya meningkatkan pengetahuan professional dan praktik pembelajaran oleh guru (Xu and Pedder, 2015). Melalui proses bersiklus, komunitas belajar professional dalam format lesson study kualitas pembelajaran di sekolah dasar menunjukkan peningkatan dari 40,91\% menjadi $56,25 \%$ untuk kelas rendah dan dari 50,57\% menjadi 68,75\% untuk kelas tinggi (Saputra, Sudirman, Affandi, 2015).

Komunitas belajar professional merupakan perkumpulan guru yang secara berkelanjutan membangun kolaburasi untuk saling berbagi ide dan solusi terhadap permasalahan pembelajaran yang muncul dalam aktifitas keseharian guru. Tujuan utama pengembangan komunitas belajar 
professional adalah untuk meningkatkan kualitas pembelajaran melalui identifikasi masalah, saling berbagi ide dan solusi, serta kebebasan untuk menguji coba solusi. Dalam implementasinya, komunitas belajar professional terdiri dari 4 komponen, yaitu kolaburasi guru untuk perbaikan pembelajaran, dukungan sumber daya, kesempatan belajar secara kolaburatif, dan modal sosial sekolah (Ermiana, Affandi, Makki, 2017).

Uji coba keefektifan model komunitas belajar professional yang telah dilakukan menunjukkan adanya peningkatan yang signifikan dari kemampuan guru melaksanakan pembelajaran. Uji coba model komunitas belajar professional bagi guru dimulai dengan kegiatan pengisian catatan harian yang bertujuan mengidentifikasi masalah pembelajaran yang dihadapi guru. Setelah itu guru melakukan diskusi harian yang bertujuan mengeksplorasi akar masalah yang telah ditemukan melalui pengisian catatan harian. Hasil eksplorasi akar masalah tersebut kemudian dijadikan bahan diskusi mingguan yang akan menghasilkan alternatif solusi yang akan diujicoba oleh guru. Dengan rancangan eksperimen repeated treatment, model komunitas belajar tersebut ditemukan signifikan dalam meningkatkan kinerja guru dalam menyelenggarakan pembelajaran (Ermiana, Affandi, Saputra, dan Witono, 2018).

Berdasarkan bukti empiris di atas, maka pengembangan komunitas belajar professional sebagai alternatif solusi untuk mengatasi permasalahan yang dihadapi guru sebagaimana digambarkan pada bab sebelumnya dianggap sangat layak. Prosedur implementasi komunitas belajar professional bagi guru sekolah dasar adalah:

\section{Pengisian catatan harian}

Pengisian catatan harian merupakan aktifitas guru dalam melakukan refleksi terhadap pembelajaran yang dilakukan (format terlampir). Catatan harian guru berisi deskripsi konkrit tentang kejadian-kejadian yang muncul dalam pelaksanaan pembelajaran, baik yang berkaitan dengan aktifitas dan perilaku siswa, penggunaan metode dan media pembelajaran, mau pun tindakan-tindakan guru selama proses pembelajaran berlangsung. Deskripsi tentang kejadiankejadian yang muncul dalam pembelajaran tersebut kemudian dibandingkan dengan kondisi yang seharusnya. Proses perbandingan tersebut pada gilirannya akan membawa guru pada masalah yang ada.

2. Diskusi harian guru

Dalam diskusi harian, guru saling berbagi masalah nyata yang mereka temukan dalam pembelajaran. Proses saling berbagi tersebut untuk menjawab pertanyaan "mengapa masalah pembelajaran muncul?". Jawaban terhadap pertanyaan ini akan membawa guru pada proses eksplorasi permasalahan sehingga sumber masalah bisa teridentifikasi.

3. Diskusi mingguan

Dalam diskusi mingguan, setiap guru diberikan kesempatan untuk mengungkapkan masalah dan sumbernya. Melalui proses brainstorming, secara bersama-sama guru merumuskan alternatif solusi yang dianggap cocok untuk menjadi solusi dari masalah yang dihadapi guru. Output dari kegiatan diskusi mingguan ini adalah daftar alternatif solusi yang bisa dipilih guru berdasarkan permasalahan yang mereka hadapi.

4. Ujicoba solusi

Alternatif solusi yang dipilih guru kemudian diuji coba untuk melihat keefektifannya. Pada tahapan ini, guru menyesuaikan rencana dan pelaksanaan pembelajaran dengan alternatif 
solusi yang dipilihnya. Proses uji coba solusi dan dampaknya terhadap masalah kemudian dituangkan lagi ke dalam catatan harian yang direfleksi secara bersama-sama dengan sejawatnya. Aktifitas mencatat proses penerapan dan dampak solusi menandai rangkaian tahapan penerapan komunitas belajar sebagai sebuah siklus yang akan terus berjalan dalam menemukan layanan pembelajaran terbaik bagi siswa.

\section{METODE PELAKSANAAN KEGIATAN}

Kegiatan pengabdian kepada masyarakat ini akan dilaksanakan dengan model workshop. Dalam kegiatan ini tim peneliti lebih banyak memposisikan diri sebagai fasilitator yang bertugas memberikan masukan agar peserta lebih terarah dalam menghasilkan produk kegiatan, yaitu rencana pengembangan komunitas belajar professional di sekolah. Untuk menghasilkan produk tersebut, tentunya guru di sekolah sasaran harus melakukan identifikasi potensi dan hambatan dalam pengembangan komunitas belajar professional. Proses identifikasi tersebut akan lebih baik jika dilaksanakan dengan brainstorming di antara para guru. Dalam proses brainstorming tersebut tim pengabdian berposisi sebagai pendamping yang bertugas memastikan alir diskusi terarah pada pemetaan potensi dan hambatan yang ada di sekolah.

Metode yang akan digunakan dalam kegiatan pengabdian ini adalah ceramah dan Tanya jawab, diskusi kelompok kecil, dan diskusi kelas. Metode ceramah dan tanya jawab dijadikan sebagai cara tim pengabdian dalam mentransfer informasi tentang komunitas belajar professional yang meliputi definisi dan karakteristik komunitas belajar professional, kondisi prasyarat pengembangan komunitas belajar professional, serta prosedur implementasi komunitas belajar professional. Metode diskusi kelompok kecil digunakan untuk memfasilitasi guru di sekolah sasaran melakukan pemetaan potensi dan hambatan pengembangan komunitas belajar professional. Dalam metode diskusi kelompok kecil ini, tim pengabdian berperan sebagai fasilitator yang bertugas memandu diskusi sehingga tujuan pemetaan potensi dan hambatan pengembangan komunitas belajar professional bisa dicapai. Setelah kelompok guru memiliki peta potensi dan hambatan dimaksud, tim pengabdian kemudian memfasilitasi guru untuk merumuskan langkah-langkah yang akan ditempuh untuk membangun komunitas belajar yang di dalamnya guru memiliki keleluasaan untuk berbagi masalah dan solusi pembelajaran yang mereka hadapi di dalam kelas. Setelah setiap kelompok berhasil merumuskan langkah pengembangan komunitas belajar, tim pengabdian kemudian memandu diskusi kelas di mana setiap kelompok diberikan kesempatan untuk mempresentasikan ide dan rencananya masing-masing. Dalam setiap presentasi, kelompok lain diminta untuk memberikan masukan sehingga ide dan langkah pengembangan komunitas belajar professional menjadi lebih baik.

\section{HASIL DAN PEMBAHASAN}

\section{Pelaksanaan Kegiatan}

Kegiatan pengabdian kepada masyarakat ini dilaksanakan tanggal 8 Agustus 2019, bertempat di SDN 30 Mataram. Kegiatan dihadiri oleh perwakilan guru dari SDN 10 Mataram dan SDN 30 Mataram sejumlah 27 orang. Kegiatan ini bertujuan untuk memfasilitasi guru mengidentifikasi 
tantangan dan melakukan perencanaan pengembangan komunitas belajar professional di sekolah masing-masing.

Kegiatan dibuka dengan sambutan dari Kepala SDN 30 Mataram sebagai tuan rumah. Dalam sambutannya, Kepala SDN 30 menyatakan pentingnya melakukan perubahan cara mengajar guru sehingga tujuan pembelajaran bisa tercapai. Upaya melakukan perubahan tersebut membutuhkan kerja sama internal sekolah dan dukungan eksternal, salah satunya adalah dari akademisi. Secara internal, warga sekolah di SDN 30 Mataram masih memerlukan dorongan untuk menciptakan suasana pembelajaran yang kondusif, menyenangkan, dan efektif. Sambutan kepala SDN 30 Mataram kemudian diakhiri dengan ucapan selamat datang dan terima kasih kepada tim pelaksana kegiatan.

Kegiatan kemudian dilanjutkan dengan sesi penyampaian materi tentang komponen, prinsip, dan keefektifan Komunitas Belajar Profesional (KBP) dalam meningkatkan keterampilan mengajar guru. Sesi penyampaian materi bertujuan untuk membantu guru memahami hakikat, karakteristik, kondisi prasyarat, komponen, serta prosedur pengembangan komunitas belajar professional bagi guru SD. Dalam presentasinya, tim pelaksana kegiatan menyampaikan bahwa perbaikan kinerja guru, khususnya yang berkaitan dengan kemampuan guru menyelenggarakan pembelajaran merupakan kebutuhan yang sangat mendesak untuk dipenuhi. Fakta bahwa kinerja guru menentukan hasil belajar siswa sudah tidak bias dibantah lagi. Sayangnya, proses pengembangan profesionalisme guru seringkali tidak menyentuh akar masalah rendahnya kemampuan guru mengelola pembelajaran, terutama yang berkenaan dengan keterampilan mengajar guru.

Salah satu alternative yang cukup menjanjikan dan efisien adalah pengembangan komunitas belajar professional di mana guru bisa saling berbagi ide, mencoba solusi, dan melakukan refleksi bersama. Pada dasarnya, komunitas belajar professional merupakan bentuk-bentuk komunikasi antarguru yang isinya berkaitan dengan isu-isu actual aktifitas pembelajaran di kelas. Sejatinya, setiap sekolah memiliki komunitas yang beranggotakan guru dan warga sekolah lainnya. Yang membedakan komunitas belajar professional dengan komunitas biasa adalah konten komunikasi serta aktifitas yang muncul dari kegiatan komunikasi tersebut. Dalam KBP, guru mendiskusikan masalah pembelajaran yang dihadapinya, mendapatkan masukan dan ide sebagai solusi, dan menindaklanjuti ide tersebut dengan aksi nyata. Aksi uji coba solusi dilaksanakan secara kolaburatif dengan warga sekolah yang lain. Proses uji coba solusi tersebut kemudian ditindaklanjuti dengan refleksi untuk menakar keefektifannya. Siklus kegiatan dalam KBP akan terus berlangsung selama proses pembelajaran di kelas terjadi. Oleh sebab itu, KBP dianggap sebagai alternative pengembangan kapasitas mengajar guru berbasis masalah nyata yang terjadi dalam pembelajaran di kelas.

Dalam sesi diskusi dan tanya jawab dengan tim pelaksana pengabdian, beberapa guru bertanya tentang peran kepala sekolah dalam penyelesaian masalah guru serta keengganan guru untuk saling berbagi keluh kesah dengan sesama guru. Menanggapi hal tersebut, tim pelaksana mengungkapkan bahwa kepala sekolah berperan sebagai fasilitator dalam menyelesaikan masalah pembelajaran yang dihadapi guru. Pada dasarnya guru lah yang memiliki tanggung jawab untuk mengidentifikasi masalah, menemukan penyebab masalah, dan memecahkan masalah pembelajaran. Pada konteks itulah kepala sekolah dituntut untuk membantu guru sehingga permasalahan yang dihadapi guru bias terselesaikan. 


\section{Hasil Kegiatan}

Kegiatan pengabdian kepada masyarakat ini menghasilkan beberapa hal yang berkaitan dengan rencana pengembangan KBP beserta langkah mengatasi hambatan pengembangan KBP. Selain itu, berdasarkan antusiasme guru dalam kegiatan diskusi membedah konsep KBP diperoleh kesimpulan bahwa guru memiliki pemahaman dan ketertarikan untuk mengembangkan KBP sebagai alternative wadah untuk meningkatkan kompetensi professional mereka.

Rencana yang akan dilaksanakan guru dalam mengembangkan KBP dapat diklasifikasi menjadi:

\section{Menyiapkan sarana pendukung KBP}

Keberadaan KBP membutuhkan dukungan sumber daya yang memadai, baik sumber daya fisik mau pun sumber daya intelektual dan emosional. Dalam kaitan dengan sumber daya fisik, KBP membutuhkan sarana seperti ruangan yang memadai untuk berdiskusi, papan whiteboard beserta alat tulis yang tersedia di ruang guru, serta dukungan berupa jaringan internet yang mendukung. Ruangan yang dibutuhkan dalam pengembangan KBP tidak harus berbentuk ruangan pertemuan khusus, melainkan ruangan yang telah ada (ruang guru misalnya) bias disetting sehingga memudahkan guru untuk saling berbagi ide dan solusi mengenai masalah pembelajaran yang mereka hadapi. Fasilitas lain seperti whiteboard dan alat tulis dibutuhkan ketika komunikasi dan diskusi antarguru harus divisualkan dalam bentuk tulisan. Jaringan internet dibutuhkan untuk memudahkan guru mengakses inovasi yang mereka butuhkan sebagai inspirasi solusi. Sarana-sarana tersebut sejatinya merupakan kebutuhan dasar yang tidak terlalu mahal dan sangat mudah untuk disiapkan.

2. Membangun budaya sekolah yang relevan dengan KBP

Budaya sekolah berkaitan dengan nilai, norma, dan kebiasaan yang menjadi rutinitas di sekolah. Budaya sekolah menentukan apa yang difikirkan, apa yang dibicarakan, serta apa yang dikerjakan oleh warga sekolah. Norma sebagai kaidah berperilaku menentukan bagaimana warga sekolah berfikir, berkomunikasi, dan bertindak. Pengembangan KBP sebagai wadah pengembangan kapasitas professional guru membutuhkan budaya sekolah sebagai fondasi yang di atasnya jalinan kerja sama dan kolaburasi guru terfokus pada perbaikan pembelajaran bagi siswa. Beberapa nilai dan norma yang dianggap guru penting dikembangkan sebagai fondasi KBP adalah saling percaya, sikap empati, kesetaraan antarguru, kohesifitas dan sikap kekeluargaan, sikap saling berbagi dan keterbukaan, serta kemauan belajar. Sikap dan kebiasaan tersebut dianggap guru sebagai sikap yang penting dimiliki oleh warga sekolah dalam upaya membangun kolaburasi untuk menyediakan layanan belajar yang optimal bagi siswa.

3. Mengintegrasikan KBP ke dalam program kerja kepala sekolah

KBP merupakan wadah yang membutuhkan dukungan dan kerja sama dari semua fihak, mulai dari guru, kepala sekolah, orang tua siswa, stakeholder pendidikan lainnya. Keberlangsungan KBP dalam membangun kebersamaan guru menciptakan lingkungan belajar yang efektif bagi siswa membutuhkan pendekatan yang terstruktur dan terorganisir. Oleh sebab itu, KBP perlu menjadi bagian dari program kerja yang dicanangkan kepala sekolah sebagai manajer. Hal-hal penting yang perlu direncanakan kepala sekolah dalam program kerjanya adalah menjadwalkan kegiatan diskusi rutin antarguru untuk membahas pembelajaran siswa dan kemajuan sekolah pada umumnya, membentuk kelompok kerja guru di sekolah (misalnya kelompok kerja guru kelas tinggi, kelompok kerja guru kelas rendah, dan lain sebagainya), mengalokasikan dana 
sekolah untuk kegiatan KBP, serta membentuk pengurus KBP yang bertugas merencanakan, melaksanakan, dan mengevaluasi kegiatan KBP. Selain itu, diperlukan juga dukungan kepala sekolah dalam menyusun jadwal mengajar guru yang fleksibel dan memungkinkan guru untuk mengujicoba solusi terhadap masalah pembelajaran yang mereka hadapi.

Selain perencanaan, kegiatan workshop pengembangan KBP ini juga membantu guru mengidentifikasi tantangan yang potensial mereka hadapi. Beberapa tantangan tersebut antara lain:

1. Ketiadaan manajemen KBP.

2. Dukungan ahli yang masih kurang

3. Budaya sekolah yang bertentangan dengan prinsip KBP

4. Manajemen sekolah yang kurang akomodatif terhadap eksistensi KBP

5. Kurangnya dukungan kepala sekolah

6. Serta instrument KBP yang perlu diperbaiki kualitasnya

\section{PENUTUP}

\section{Simpulan}

Berdasarkan pelaksanaan Pengabdian Kepada Masyarakat diatas, diperoleh beberapa poin penting sebagai simpulan yaitu sebaga berikut.

1. Guru memiliki antusiasme dan keinginan untuk membangun komunitas belajar professional sebagai alternative pengembangan professional dan media berbagi ide dan solusi untuk meningkatkan kualitas pembelajaran bagi siswa

2. Beberapa tantangan yang dihadapi guru dalam mengembangkan komunitas belajar professional di sekolah antara lain budaya sekolah yang tidak sesuai dengan prinsip-prinsip komunitas belajar professional, kurangnya dukungan dari tenaga ahli dan kepala sekolah, serta manajemen sekolah yang tidak akomodatif terhadap pengembangan komunitas belajar professional

3. Rencana yang akan dilaksanakan oleh guru dalam mengembangkan komunitas belajar professional antara lain menyiapkan sarana pendukung komunitas belajar professional, mengembangkan budaya sekolah yang lebih suportif terhadap eksistensi komunitas belajar professional, serta menjadikan pengembangan komunitas belajar professional sebagai bagian dari program kerja kepala sekolah

\section{Saran}

1. Diperlukan pendampingan terhadap guru dan kepala sekolah secara lebih terorganisir dalam menciptakan budaya dan suasana sekolah yang lebih sesuai untuk pengembangan komunitas belajar professional

2. Dalam rangka mengatasi tantangan yang dihadapi guru dalam pengembangan komunitas belajar professional, dibutuhkan jalinan kemitraan antara sekolah dengan lembaga pendidikan tinggi melalui penyediaan expert yang secara berkelanjutan dan terprogram berkolaborasi dalam membangun komunitas belajar profesional 


\section{DAFTAR PUSTAKA}

Borich, G.D. 1996. Effective Teaching Methods, Third Edition. New Jersey; Prentice Hall

Ermiana, I., Affandi, L.H. Makki, H.M. 2017. Pengembangan Model Komunitas Belajar Profesional Untuk Meningkatkan Kinerja Guru Sekolah Dasar. Mataram; LPPM Universitas Mataram, Laporan Penelitian, tidak dipublikasi

Ermiana, I., Affandi, L.H., Saputra, H.H., dan Witono, A.H. 2018. Pengembangan Model Komunitas Belajar Profesional Untuk Meningkatkan Kinerja Guru Sekolah Dasar. Mataram; LPPM Universitas Mataram, Laporan Penelitian, tidak dipublikasi

Husniati., Affandi, L.H., Saputra, H.H., Makki, H.M. 2016. Study Tentang Kinerja Mengajar Guru Se-Kota Mataram. Mataram; Laporan Penelitian

Marzano, R.J. 2007. The Art and Science of Teaching: A Comprehensive Framework for Effective Instruction. Alexandria, VA; ASCD

Saputra, H.H., Sudirman, Affandi, L.H. 2015. Pendampingan Pengelolaan Program Lesson Study Berbasis KKG di SDN 1 dan SDN 2 Kekeri. Jurnal IImiah Widya Pustaka Pendidikan, 3(2); 91-103

Xu, H., and Pedder, D. 2015. Lesson Study: an International Review of The Research. In Peter Dudley (ed.). Lesson Study: Professional Learning for Our Time. p. 29-58. New York; Routledge 